\section{Diversity of Capitalism in the New EU Member States}

Eric Magnin

LADYSS, Department of Economics, University of Paris, Paris, France

\section{Synonyms}

Comparative analysis of capitalism; Economic systems; Varieties of capitalism

\section{Introduction}

In the early 1990s, Central and Eastern European Countries (CEECs) embarked on a major transformation of their economic and political systems. The aim was to move away from the Soviet-inspired socialist system toward the West European type of economic system, generally described as a market economy. This was an unprecedented, large-scale phenomenon of economic, social, and political change. The "transition to a market economy" gradually gave way to another process of institutional change, the process of integration into the European Union (EU), which involved reforms aimed at ensuring the conformity of CEEC institutions with EU legislation.

This twofold transformation process has led specialists to question the type of economic model likely to emerge from these successive reforms (Chavance and Magnin 2002). Market economy is indeed a vague and theoretical concept, which does not correspond to the reality of economies in developed countries. There are actually a variety of models of capitalism at the international level, with different economic and social performances. But this diversity becomes only evident at the institutional level. Indeed, at a relatively high level of abstraction, contemporary developed economies appear relatively similar. What they have in common is the existence of a labor market, a market for goods and services, a financial market, a two-tier banking system (central bank/commercial banks), a system of income distribution, and so on. However, on closer examination, national institutional forms are relatively diversified. For example, the French tax regime has nothing in common with its American counterpart. The social protection system is not the same in France as in Great Britain or Japan. These various institutional configurations exhibit a relative coherence that allows them to be grouped into "models" of capitalism.

The "transition to a market economy" has helped to stimulate work in the field of the comparative analysis of capitalism and brought to light several approaches. The CEECs constitute a privileged field of application for this research. 


\section{The Comparative Analysis of Capitalism}

Since 1990, many works have contributed to enrich the comparative analysis of capitalism. However, two major approaches, toward which all the others seem to converge, stand out in this profusion: the so-called "varieties of capitalism" (VoC) approach proposed by Hall and Soskice (2001) and the régulationist-inspired approach promoted by Amable (2003), in the path traced by Boyer (1990).

The varieties of capitalism approach is focused on the firm as the major actor in the capitalist economy, whose success is based on the development and exploitation of its core competencies or "dynamic capabilities" (Hall and Soskice 2001). It emphasizes the relational dimension of the firm. A firm's success depends largely on the quality of the relationships it has been able to establish with internal (employees) and external actors (suppliers, customers, shareholders, unions, employers' organizations, the state, etc.). Coordination issues are therefore at the heart of the VoC approach.

Hall and Soskice identify five spheres of activities in which companies will have to solve coordination problems decisive for the exploitation and development of their core competencies: industrial relations, vocational training and education, corporate governance, interfirm relations, and relations with their own employees. There are two major ways of solving these coordination problems, which differentiate the two main types of capitalism in developed economies: coordination based on market mechanisms, typical of liberal market economies (LMEs), and nonmarket coordination or "strategic interaction," characteristic of coordinated market economies (CMEs).

The VoC approach can be considered as a neoinstitutionalist approach, as attested by references to North, Williamson, and Aoki (Chavance 2008). Indeed, it gives an important role to formal and informal institutions, to the market-hierarchy dichotomy, with the idea that institutions, whose historical dimension is underlined, facilitate the coordination of interrelations between actors.

Germany is the typical example of a coordinated market economy. Nonmarket coordination prevails in the various spheres of activities. The United States is the textbook case of the liberal market economy, where coordination problems in the different spheres are solved mainly through market relations.

The VoC approach, which is based on a distinction between two types of capitalism, is reminiscent of the division made by M. Albert (1993) between Rhenish capitalism and Anglo-Saxon capitalism. It offers a clear theoretical framework for comparing different national economies, but with one dimension in particular, the firm and its coordination problems, and one separation criterion, the market's role. Consequently, this binary classification does not allow for the integration of all the developed economies, as Hall and Soskice (2001, p. 21) themselves acknowledge by referring to the "more ambiguous positions" of some Southern European countries (France, Italy, Spain, Portugal, Greece).

The other theoretical framework, which falls within the field of the comparative analysis of capitalisms, is the one proposed by Amable (2003) and before him by Boyer (1990), who criticizes the unidimensional vision of $\mathrm{VoC}$ and prefers an approach that highlights the diversity of capitalism by relying on a typology of five models. This approach is part of an institutionalist theoretical framework in economics, within the tradition of the French school of régulation (Boyer 1990). Régulation theory focuses on the diversity of institutional configurations in time and space, of the modes of régulation which give them their coherence, and of the accumulation regimes which they underlie.

Amable (2003) identifies a number of "key institutional domains" (very close to the canonical forms of the Régulation theory) in which OECD countries show significant differences. These include competition on product markets, wagelabor nexus and labor market institutions, financial intermediation and corporate governance, social welfare, and education systems. Amable's study is based on data analysis, i.e., a principal component analysis associated with an ascending hierarchical classification, applied to 21 OECD countries to reveal the existence of 5 types of capitalism. These are the market-based model or 
Anglo-Saxon capitalism (the United States, the United Kingdom, Canada, Australia), the social democratic model (Sweden, Finland, Denmark), the continental European model (France, Germany, Austria, Belgium, the Netherlands, Switzerland, Norway), Mediterranean capitalism (Italy, Spain, Portugal, Greece), and Asian capitalism (Japan, South Korea). However, each model of capitalism can be considered as an ideal type, to which no real economy perfectly corresponds. To briefly outline a few features of each model, the market-based model is relatively similar to LMEs, as the role of the market is predominant in the different institutional domains. Social democratic capitalism is characterized by a high level of social protection, supportive industrial relations, and an important role of the state. The continental European model is not that far, with greater employment protection and more conflictual labor relations. The Mediterranean model shows a dual labor market, weaker social protection, and an education system focusing on the acquisition of general skills. As for Asian capitalism, it is marked by the weight of large conglomerate companies, supportive labor relations, weak social protection, and low level of public spending on education.

Since 1990, the comparative analysis of capitalisms has also been enriched by integrating the concepts of institutional complementarity and hierarchy.

Two institutions can be described as complementary when "the existence or the particular form taken by an institution in one area reinforces the presence, functioning or efficiency of another institution in another area" (Amable 2003, p. 60). The concept of institutional complementarity is shared by both the $\mathrm{VoC}$ and the diversity of capitalism approaches. The example of complementarity between financial and education systems illustrates the concept (Amable 2003). A financial system dominated by financial markets favors the pursuit of short-term profitability, which results, on the employment side, in a low commitment of the firm to its workers and a high risk of layoffs. Under these conditions, employees will prefer to acquire general rather than firmspecific skills to facilitate their redeployment to other firms. A financial system dominated by banks stimulates long-term investment, which in turn promotes stable compromises between social partners that encourage the acquisition of specific skills. In both cases, each institution reinforces the influence of the other. The abovementioned CMEs and LMEs also exhibit complementary relations between their founding institutions.

The concept of institutional complementarity has a number of implications that are worth emphasizing. First, a model of capitalism is not a collection of institutional forms, randomly brought together, but a particular combination of these forms linked by complementary relations. This results in a relative systemic coherence. Second, it becomes difficult, theoretically and empirically, to correlate an economic performance with a single institution because of this interdependence among institutions. It is a configuration of complementary institutional forms "making a system" that is responsible for the overall performances of the model.

Thirdly, it is therefore not advisable to design an optimal institutional configuration, which would combine institutions from different countries that are considered to be the most "successful" in each area: for example, the US labor market regulations and tax system, the Swedish education system, the Danish employment policy, etc. Importing into one type of capitalism an isolated institutional form from another model could lead to an unsustainable configuration. One can then question, for example, the coherence of the association between labor market flexibility and "generous" social welfare, the famous "flexicurity," as well as the very widespread use of institutional benchmarking practices. On the other hand, different configurations of complementary institutions might produce similar macroeconomic performances. This was the case with the Anglo-Saxon model and the social democratic model in the 1990s (Aiginger 2005). This is also the basic assumption of the $\mathrm{VoC}$ approach, at the root of the CME-LME dichotomy.

The concept of institutional hierarchy, for its part, is mainly present in the approach of the diversity of capitalism and is part of the more recent régulationist work (Amable 2003). 
It expresses the idea that an institutional form plays a dominant role in relation to the others at a given point in time, both in the organization of complementary relations and in the dynamic evolution of the institutional architecture. The authors recognize the formation of this hierarchy as an expression of power relations and political compromise. But it is the emergent, unintended result of an unplanned process of confrontation of vested interests at a given point in time. The primacy of the wage-labor nexus, favorable to workers, in the Fordist period (1945-1975) is the outcome of the sociopolitical compromises that emerged in the post-war period in response to the previous dramatic episode. Since the 1980s, this hierarchy has been called into question in favor of other institutional forms: competition conditions for some specialists and finance for others.

The notion of institutional hierarchy also calls for further remarks. Institutional hierarchy and complementarity appear to be distinct but related concepts. Indeed, one of the expressions of the hierarchy lies in the influence, through constraints and incentives, that the dominant institution exerts on the modalities of complementarity within a given institutional configuration. It leads the other institutions to strengthen it, even if it means making them evolve a little. For example, the priority given to workers during the Fordist period has led other institutional forms to be articulated in such a way as to strengthen it. Or else, the predominance of finance in the recent period has led to a change in the wage-labor nexus and social welfare, which have now been challenged by finance.

From a dynamic perspective, one can imagine a shift in the institutional hierarchy according to the evolution of political power relations, which does not necessarily mean a change in the model of capitalism.

\section{Application to the New EU Member States}

While the post-socialist transformation has contributed to the development of work on the diversity of capitalism, the Central and Eastern European countries, which entered the European Union in the mid-2000s, constitute in turn a privileged field of application for the comparative analysis of capitalist models. Many authors have thus tried to apply the two previously presented analyses, the $\mathrm{VoC}$ and the régulationist approaches, to transition economies.

In the framework of the VoC approach, some specialists argue that Estonia and Slovenia can be considered as very good examples of, respectively, a liberal market economy and a coordinated market economy. Among the different spheres of activities at the center of the $\mathrm{VoC}$ approach, Feldmann (2006) focuses more particularly on industrial relations. He shows that the Slovenian model "represents a consensual and coordinated approach to industrial relations and social dialogue, with strong employers' organizations and unions, and also exceptionally high coverage of collective agreements" (Feldmann 2006, p. 841). By contrast, the Estonian industrial relations system exhibits all the characteristics of LMEs with decentralized wage negotiations, limited coverage of collective agreements and weakness of both unions and employers' organizations. Buchen (2007) confirms Feldman's results and extends his analysis of industrial relations to the other VoC activity spheres and to the dynamics of comparative institutional advantages. He shows that both countries exhibit a high degree of institutional complementarity. In Slovenia, the industrial relations system is consistent with a highly protected labor market, while the vocational training system provides specific skills. In Estonia, industrial relations and labor market features are complementary to a vocational training system reorganized toward general education. Trade figures and patterns of foreign direct investment complete the picture and reveal comparative institutional advantages of CME type in Slovenia and LME type in Estonia. As the VoC approach predicts, different clusters of complementary institutions may result in equally good macroeconomic performances. This has been the case for Slovenia and Estonia during the transition process.

For their part, Nölke and Vliegenthart (2009) propose another way of applying the $\mathrm{VoC}$ 
approach to Central Eastern European countries, inspired by King's work (2007). For the latter, these economies (Hungary, Poland, the Czech Republic) can be described as dependent liberal capitalism. Referring to the different spheres of activities of the $\mathrm{VoC}$ approach, he qualifies them in the following way: liberal industrial relations related to employees' demobilization in the postsocialist world (weak trade unions), an education system that no longer meets the companies' needs, and a corporate governance dominated by foreign banks. The key element of the model is the weight of foreign investors in banks and other companies' capital. Economic performances depend on the strategy of industrial and financial transnational corporations (TNCs), which provide capital, technology, skills, and access to global markets. King contrasts this model to the postcommunist patrimonial capitalism (Russia, Ukraine, Romania), marked by the collusion of political and economic elites and the central role of cronyism, which invades all VoC spheres (no corporate governance, neopaternalist industrial relations, etc.). Beyond his reference to the VoC, King considers that the former socialist countries represent two specific models, a little bit far from the LME and CME logic.

More in line with the VoC approach than King, Nölke and Vliegenthart (2009) consider that, at the end of their transition/accession process, CEECs are now constituting a third variety of capitalism on the same level as the CMEs and LMEs, the DMEs or "dependent market economies." The relations between the founding institutions of this new model reflect a strong complementarity. The main characteristic of the DMEs is the weight of foreign direct investment (FDI) in the economy, which creates a real dependence on foreign capital. The dominant coordination mechanism in the economy is then based on intra-firm hierarchies within multinational firms. Industrial relations and labor market hold an intermediate position between LMEs and CMEs, more competitive than in the latter case but less liberal than in the former one, in order to be able to retain the workforce and limit social unrest and the disruption of production chains. Tax revenues are limited by a tax regime favorable to FDI and by tax competition among CEECs, which in turn reduces public spending, especially in the field of education. In any case, most research and development is carried out in countries where TNCs have their headquarters and transferred back into the production processes of subsidiaries. These various elements allow DMEs to develop a comparative advantage in the production and assembly of relatively complex consumer goods, which can then be exported worldwide.

Other authors have applied the régulationist approach of the diversity of capitalism and the statistical method used by Amable to Eastern European economies.

For example, Mykhnenko's work (2007) is focused on two countries, Poland and Ukraine, from the mid-1990s to the mid-2000s. Both countries share some institutional characteristics which are designing an original model of "postcommunist capitalism" but still "at a formative stage." Their financial system is notably underdeveloped compared to Western European economies. In his article, the author refers to Poland and Ukraine as hybrid forms, "mixed or weakly coordinated market economies" (MMEs). Mykhnenko concludes that the post-communist emerging model in Poland and Ukraine presents a certain degree of institutional complementarity which could (partially) explain the positive socioeconomic developments experienced by both countries in the early 2000s.

For her part, Farkas (2011) includes all the new member states (except Croatia) in her study. Her data provide a picture of Central and Eastern Europe around the mid-2000s. She demonstrates that an original model of capitalism is emerging in post-socialist Europe. This "Central and Eastern European model" can be considered as different from other existing models in the "old Europe." Only Slovenia could be related to the Continental model of capitalism. In an attempt to bring this new post-socialist capitalism closer to Amable's typology, it would roughly be somewhere in between the Continental and the Mediterranean models, despite some rare similarities with the Anglo-Saxon model, depending on the institutional area under study. The Central and Eastern 
European capitalism is the path-dependent outcome of post-socialist transformation trajectories. According to Farkas, the lack of capital, weak civil society, and the influence of international organizations and the EU on structural reforms are the main initial conditions behind that outcome. Therefore, this new model of capitalism cannot be considered as a transient configuration but rather as a permanent one. Unfortunately, the post-socialist capitalism could even be locked in a lesser path of development because of the fundamental asymmetrical position between the old Europe and its periphery in the international division of labor.

Finally, some specialists have developed their own typologies, considering that both previous approaches were not adapted to the reality of Central and Eastern European countries.

Drahokoupil and Myant (2011) argue that neither the $\mathrm{VoC}$ approach nor Amable's régulationist approach is able to analyze the diversity of capitalism in the region. Indeed, the authors state that the comparative analysis of capitalisms in general has been elaborated on the example of developed countries and that this framework is not suitable for transition economies, because of their specificities (external imbalance, emergent institutional framework, legacy of the socialist system, unstabilized economic relations). In their view, the essential point is integration into the world economy, which is related to the problem of current account deficit financing. They distinguish six forms of "international integration" that can be observed more or less in the different countries during the 2000s. The first one relies on foreign direct investment in high value-added export sectors. It is found mainly in the countries of Central and Eastern Europe. The second is similar to the first one, but without FDI. Slovenia, some Czech companies, and Belarus are involved to some extent. The third depends on subcontracting relations with TNCs and is based on exports of noncomplex manufactured products such as clothing or simple components. It can be observed in the Baltic and Southeastern European countries. The fourth is based on exports of raw materials, especially oil and gas, and concerns mainly the CIS. The fifth depends on current transfers from abroad (remittances, financial aid from international organizations). Finally, the last one refers to growth financialization, where private sector activity and household consumption are fuelled by foreign bank credit. Hungary, Baltic countries, Romania, Ukraine, etc., thus "benefited" from the liquidity abundance in the world in the 2000s. By combining forms of international integration and institutional characteristics (ownership forms, role of the state, etc.), the authors identify then five specific forms of capitalism in transition economies: (second-rank) economies based on FDI (East-Central Europe), peripheral market economies (Baltic states, Southeastern Europe), oligarchic or clientelistic capitalism (Russia and some CIS countries), order states (Belarus, Uzbekistan), and economies based on remittances and international aid (Albania, Moldova, Armenia).

Bohle and Greskovits (2012) also propose a distinct typology, inspired by K. Polanyi's work, to group together the new EU members in the 2000s: the pure neoliberal capitalism, the embedded neoliberal capitalism, and the neocorporatist model. They focus on three important differentiation factors: initial political choices marked by the "perceived" legacy by the actors, the role of uncertainty and crises in the evolution of the pursued strategies, and the influence of transnational actors. The Baltic countries provide a good example of neoliberal capitalism. They have radically liberalized their economies: flexible labor market, weak social protection, and tax incentives, all of which satisfy foreign investors. Their exports are based on low value-added branches, which are low-skill labor- and resource-intensive or associated with their activities as TNCs' subcontractors. Their strength is related to their macroeconomic stability, achieved as a result of fiscal and monetary discipline. The Visegrad countries are characterized by embedded neoliberalism. Economic liberalization has been less far-reaching than in the previous case, and the welfare state has been partly preserved, thus strengthening social cohesion. A favorable legacy and an incentive policy have fostered foreign capital inflows leading to the development of an export-oriented sector, relatively intensive in skilled labor and technology, 
in which automobile industry plays a central role. However, macroeconomic stability was not always achieved. Finally, neo-corporatism is the privilege of only one country, Slovenia, which combines gradual liberalization, social inclusion (based on social protection and institutionalized bargaining between social partners), and macroeconomic stability.

\section{Conclusion}

The comparative analysis of capitalism has developed substantially since the 1990 s, especially in the context of the transition to a market economy in Central and Eastern European countries. Two approaches are currently dominating this field of research: the $\mathrm{VoC}$ approach and the régulationist diversity of capitalism. Their application to the new EU member states has shown their relevance and brought to light new economic models or alternative typologies. Which model seems the most meaningful today to describe the reality of CEEC economies? Dependent capitalism is undoubtedly the one that has generated the most interest and discussion. However, as each model is constantly evolving under the action of both internal and external forces, the Covid-19 crisis will certainly have an impact not only on dependent capitalism but also on other models of capitalism, weakening some or strengthening others.

\section{Cross-References}

- Dependent Capitalism and Monetary Regimes: The Case of the Balkan Countries

- Globalization and Capitalism

- Power and Politics in the European Union

- The Mixed Socialist-Capitalist Models

- The Socialist and Capitalist Models

\section{References}

Aiginger K (2005) Towards a new European model of a reformed welfare state: an alternative to the United States Model. In: Economic survey of Europe, no 1. United Nations, Geneva, pp 105-114

Albert M (1993) Capitalism against capitalism. Whurr Publishers, London

Amable B (2003) The diversity of modern capitalism. Oxford University Press, Oxford

Bohle D, Greskovits B (2012) Capitalist diversity on Europe's periphery. Cornell University Press, Ithaca

Boyer R (1990) The regulation school: a critical introduction. Columbia University Press, New York

Buchen C (2007) Estonia and Slovenia as antipodes. In: Lane D, Myant M (eds) Varieties of capitalism in post-communist countries. Palgrave Macmillan, Houndmills/New York, pp 65-89

Chavance B (2008) Institutional economics. Routledge frontiers of political economy. Routledge, London

Chavance B, Magnin E (2002) Emergence of path-dependent mixed economies in Central Europe. In: Hodgson G (ed) A modern reader in institutional and evolutionary economics: key concepts. Edward Elgar, Cheltenham, pp 168-200

Drahokoupil J, Myant M (2011) Transition economies: political economy in Russia, Eastern Europe, and Central Asia. Wiley, Hoboken

Farkas B (2011) The Central and Eastern European model of capitalism. Post-Communist Econ 23(1):15-34

Feldmann M (2006) Emerging varieties of capitalism in transition countries. Industrial relations and wage bargaining in Estonia and Slovenia. Comp Pol Stud 39(7):829-854

Hall P, Soskice D (eds) (2001) Varieties of capitalism: the institutional foundations of comparative advantage. Oxford University Press, Oxford

King L (2007) Central European capitalism in comparative perspective. In: Hancké B, Rhodes M, Thatcher M (eds) Beyond varieties of capitalism. Conflict, contradictions and complementarities in the European economy. Oxford University Press, Oxford, pp 307-327

Mykhnenko V (2007) Strengths and weaknesses of 'weak' coordination: economic institutions, revealed comparative advantages, and socio-economic performance of mixed market economies in Poland and Ukraine. In: Hancké B, Rhodes M, Thatcher M (eds) Beyond varieties of capitalism. Conflict, contradictions and complementarities in the European economy. Oxford University Press, Oxford, pp 351-378

Nölke A, Vliegenthart A (2009) Enlarging the variety of capitalism. The emergence of dependent market economies in East Central Europe. World Polit 61(4):670-702 